\title{
Treatment of Antibiotics Wastewater Utilizing Successive Hydrolysis, Denitrification and Nitrification
}

W. Ma , M. Yang , J. Wang , R. Qi \& L. Ren

To cite this article: W. Ma , M. Yang , J. Wang , R. Qi \& L. Ren (2002) Treatment of Antibiotics Wastewater Utilizing Successive Hydrolysis, Denitrification and Nitrification, Environmental Technology, 23:6, 685-694, DOI: 10.1080/09593330.2002.9619253

To link to this article: http://dx.doi.org/10.1080/09593330.2002.9619253

Published online: 11 May 2010.

Submit your article to this journal $[\pi$

Џll Article views: 61

Q View related articles $\sqsubset$

Citing articles: 3 View citing articles 


\title{
TREATMENT OF ANTIBIOTICS WASTEWATER UTILIZING SUCCESSIVE HYDROLYSIS, DENITRIFICATION AND NITRIFICATION
}

\author{
W. MA ${ }^{12}$, M. YANG ${ }^{1 *}$, J. WANG ${ }^{21}$, R. Q1 ${ }^{1}$ ANDL. REN ${ }^{3}$ \\ 'State Key Laboratory of Enviromental Aquatic Chemistry, Research Center for Eco-Environmental Sciences, \\ Chinese Academy of Sciences, Beijing, 100085, China \\ 'Department of Environmental Science, Sharxi University, Taiyuan City, 030006, Shanxi Province, China \\ ${ }^{3}$ Environmental Protection Research Institute, North-China Pharmaceutical Corporation, Shijiazhuang City, \\ 050015, Hebei Province, China
}

(Received 8 May 2001; Accepted 6 January 2002)

\begin{abstract}
A process consisting of anaerobic hydrolyais, denitrification, and oxidation/nitrification was proposed for simultaneous removal of carbon and nitrogen from terramycin crystallizing mother solution (TCMS), and its performance was investigated by treating diluted TCMS in a lab-acale continuous fiow column system. Direct denitrification-ritrification of diluted TCMS produced a significant residual of nitrate and nitrite, which disappeared 44 days after startup of anaerobic hydrolysis column. The electron donors available to denitrification were increased by 6 times after diluted TCMS was treated in the hydrolysis column under an HRT of $2.5 \mathrm{~h}$ or longer. The reaction rates of organics decomposition, nitrification, and denitrification were also significantly increased due to reduction of terramycin and decomposition of complicated molecules to small molecules during anaerobic hydrolysis. The specific denitrification rate and nitrification rate increased from $0.033 \mathrm{~d}^{-1}$ and $0.01 \mathrm{~d}^{-1}$ to $0.045 \mathrm{~d}^{-1}$ and $0.021 \mathrm{~d}^{-1}$ respectively after diluted TCMS (dilution ratio: 1:4) was hydrolyzed in anaerobic hydrolysis column at a hdraulic retention time (HRT) of $4 \mathrm{~h}$.
\end{abstract}

Keywords: Terramycin crystallizing mother solution, pretreatment, biodegradability, pre-denitrification process, simultaneous carbon and nitrogen removal

\section{INTRODUCTION}

Antibiotics produced through fermentation are accompanied by a large amount of fermentation wastewater (e.g., $90-100 \mathrm{~m}^{3}$ wastewater discharged for producing one ton of terramycin) containing high concentrations of organic compounds $\left(\mathrm{COD}_{\mathrm{Cr}}, 5-80 \mathrm{~g}^{-1}\right)$ and suspended solids (SS, 0.5$\left.25 \mathrm{~g} \mathrm{t}^{-1}\right)$, which poses a serious environmental problem to China. The composition of antibiotics wastewater is very complicated, and the organic compounds at least comprise of fermentation by-products, residual substrates, residual antibiotics, etc. The biodegradability of antibiotics wastewater is relatively low due to the existence of residual antibiotics and fermentation by-products. On the other hand, a great deal of ammonia and sulfate are usually used during antibiotics production, and are left in the wastewater after use. So, antibiotics wastewater is usually also characterized by a high concentration of ammonium and sulfate in addition to organics.

With the increasing attention to water pollution problems, many efforts [1-4] have been devoted to improving the treatment efficiency of antibiotics wastewater during the last decade. It is clear that the conventional UASB process is not suitable for treating antibiotics wastewater since methane generation is easily inhibited by high concentration of sulfate. The wastewater biodegradability and $C O D$ removal rate, however, were found to be improved to a large extent by introducing anaerobic pretreatment before aerobic treatment. Most of the related works have been focused on COD removal. Since the high concentration of ammonium remained in the final effluents could lead to many environmental problems, such as toxicity to fish, 
eutrophication of receiving water bodies [5,6], it is necessary to establish a strategy for the simultaneous removal of COD and nitrogen.

Biological processes for nitrogen removal have been widely used for the treatment of sewage and some industrial $\mathbf{N}$-bearing wastewater [7]. Electron donors are needed for decomposition of nitrate in the denitrification step whereby nitrate or nitrite replaces oxygen in the respiratory processes of bacteria under anoxic conditions. In most cases, the organic pollutants in wastewater have been utilized as the electron donors. However, not all of the biodegradable organios in wastewater are available to the denitrifiers. Small molecular organic acids which are the main products of anaerobic hydrolysis are favorable electron donors to denitrification bacteria [8]. Further, nitrifiers have been considered to be a category of sensitive organisms that are susceptible to some environmental changes and certain organic compounds [9]. Little has been known about the influences of the characteristics of antibiotics fermentation wastewater on nitrification and denitrification, although it is easy to speculate that the residual antibiotics possibly have some adverse effects to these reactions from the purposes for which these medicines are used.

In this study, the possibility of simultaneous removal of carbon and nitrogen from antibiotics wastewater was investigated by using terramycin crystallizing mother solution (TCMS) as model wastewater. An anaerobic hydrolysis step, which has been considered as an effective method for improving the biodegradability of wastewater [10-12], was introduced for the purposes of increasing the amount of denitrification electron donors and improving the biodegradability of TCMS. A continuous flow column reactor system consisting of anaerobic hydrolysis, denitrification, and oxidation/nitrification was established in the laboratory.

\section{MATERIALS AND METHODS}

Wastewater

TCMS was collected from North-China Pharmaceutical Corporation (Shijiazhuang, Hebei Province). The concentration of each composition in wastewater varied from batch to batch, and Table 1 gives the variation ranges of main pollutants. The low $\mathrm{BOD}_{5} / \mathrm{COD}$ ratio indicates that the biodegradability of the solution was relatively low. The concentrations of total nitrogen (TN) and $\mathrm{NH}_{4}{ }^{-}-\mathrm{N}$ were considerably high, and about $24 \%$ nitrogen was contained in organic compounds. The high concentration of oxalic acid was due to the use of oxalic acid for $\mathrm{pH}$ adjustment during the extraction of terramycin. TCMS was preserved at $4^{\circ} \mathrm{C}$, and used for experiments after being diluted to given dilution ratios with tap water.

\section{Seed Sludge Culture and Acclimation}

Seed sludge was taken from an aeration tank of the Gaobeidian Sewage Treatment Plant (Beijing, China). It was cultured with diluted TCMS (dilution ratio, 1:49) in a 251 glass tank which was operated in a sequential cycle of anoxic period $(2 \mathrm{~h})$, aerobic period $(8 \mathrm{~h})$ and sedimentation period $(2 \mathrm{~h})$. The liquor volume was $20 \mathrm{l}$, and $5 \mathrm{l}$ supernatant in the sludge tank was replaced with fresh diluted TCMS soon after the end of the sedimentation period. A month later, denitrification/nitrification activities of the cultured sludge were observed, and seed sludge began to be inoculated to continuous flow column reactors respectively.

The feed to the seed sludge cultivation tank was changed to the same diluted wastewater supplied to the continuous flow reactors after the continuous system was started up, and switched to the effluent of the anaerobic hydrolysis column after the hydrolysis reactor in the continuous flow system began to be started up. The sludge used for the batch experiments in this study was taken from the sludge tank.

\section{Continuous Flow Experiments}

The schematic diagram of the bench scale continuous flow system is shown in Figure 1.

The system comprised of 3 acrylic columns, namely Acolumn (anaerobic hydrolysis column, $1.6 \mathrm{l}$ ), D-column (denitrification column, $2.9 \mathrm{1}$ ), and N-column (oxidation/nitrification column, $3.8 \mathrm{l}$ ). Each column was equipped with a pump to supply water and another pump was used for recycling the effluent of the N-column to the $D$ column. All of the columns were set up in a thermostatic room controlled at $25^{\circ} \mathrm{C}$. The former two were sludge bed reactors equipped respectively with a gas-liquid-solid separator, and the last one was filled with hollow polyethylene balls of a diameter of $2.5 \mathrm{~cm}(\Phi 25$, Yuhuan Company, Zhejiang Province). D-column and N-column were started up first by inoculating seed sludge (MLSS, $5000 \mathrm{mg} \mathrm{l}^{-1}$ ) to the two columns, respectively. Each column was operated separately for about a week by continuously feeding TCMS diluted 1:49. Then, the effluent of the $\mathbf{N}$-column was recycled to the D-column with a ratio to the D-column influent of 3.5 to 1 . The A-column was inoculated with seed sludge (MLSS, $5000 \mathrm{mg} \mathrm{l}^{-1}$ ) on day 50 , and the effluent was fed into the

Table 1. Average concentrations of main pollutants of TCMS (mg l-1 $\mathrm{l}^{-1}$.

\begin{tabular}{llllllll}
\hline $\mathrm{pH}$ & $\mathrm{COD}_{\mathrm{c}}$ & $\mathrm{BOD}_{5}$ & $\mathrm{TN}$ & $\mathrm{NH}_{4}^{+}-\mathrm{N}$ & $\mathrm{SO}_{1}^{2-}$ & Oxalate & Terramycin \\
\hline $4-5$ & $15000 \sim 20000$ & $1400 \sim 3900$ & $\sim 2100$ & $\sim 1600$ & $2000 \sim 4000$ & $3000 \sim 7000$ & $\sim 1000$ \\
\hline
\end{tabular}




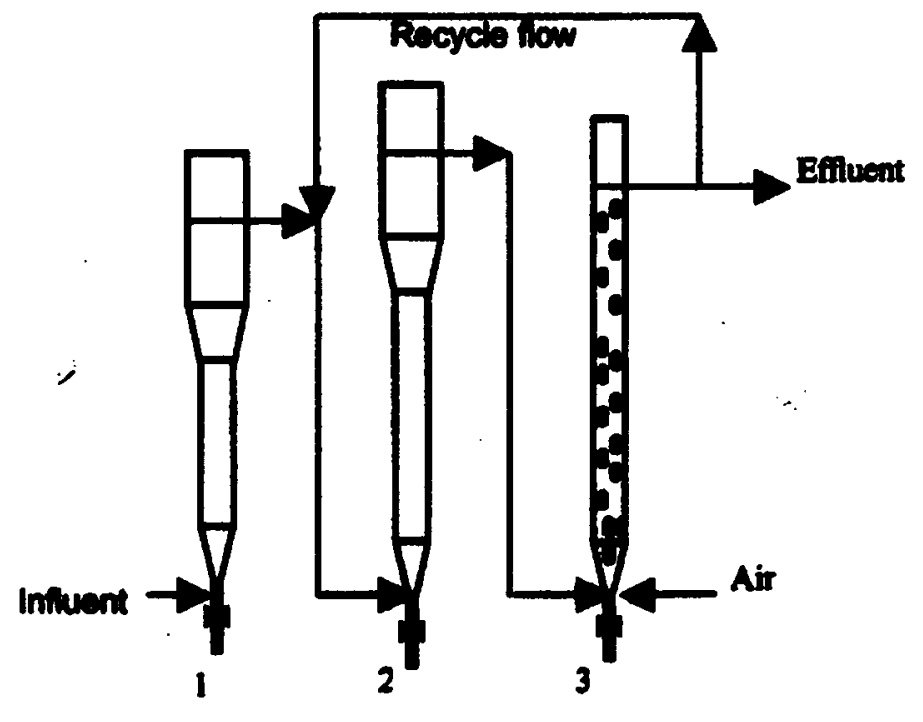

Figure 1. Schematic diagram of continuous flow column system (1: Anaerobic hydrolysis column; 2: Denitrification column 3: Oxidation/Nitrification column).

D-column from the following day.

The operation of the system could be divided into two parts. Part 1 was used for evaluating the effects of the Acolumn and the performance of the whole system, and part 2 for investigating the effects of hydraulic rention time (HRT) of the A-column on the availability of denitrification electron donors.

Part 1

The flow rates to the A-column, D-column, and $\mathrm{N}$ column were $1.05,0.64$, and $0.481 \mathrm{~h}^{-1}$, respectively, and the effluent from the $\mathrm{N}$-column was recycled to the $\mathrm{D}$-column at a rate of $2.24 \mathrm{~h} \mathrm{~h}^{-1}$. The air supplied to the $\mathrm{N}$-column was at a rate of $1801 \mathrm{~h} \mathrm{~h}^{-1}$. The dilution ratio of TCMS was reduced step by step from 1:49 to a final one of 1:4. This part of the experiment was continued for 167 days.

$\mathrm{pH}, \mathrm{COD}, \mathrm{NH}_{3}-\mathrm{N}, \mathrm{NO}_{3}^{-}-\mathrm{N}, \mathrm{NO}_{2}^{-}-\mathrm{N}$ and $\mathrm{SO}_{4}^{2-}$ in the influent and effluent of each column were monitored daily. ORPs of the A-column and D-column were measured on a daily basis when the dilution ratio was decreased to 1:4. Concentrations of organic acids in the samples of day 160 were also determined.

Part 2

The recycle of the N-column effluent to the D-column was stopped after part 1 was finished, and the effluent of the A-column was fed to the D-column after excessive $\mathrm{KNO}_{3}(500$ $\mathrm{mg} \mathrm{l}^{-1} \mathrm{NO}_{3}^{-}-\mathrm{N}$ ) was added. The HRT of A-column was varied from $1.5 \mathrm{~h}$ to $6.0 \mathrm{~h}$, and that of the D-column was fixed at $4.5 \mathrm{~h}$. The system was operated under each HRT of the A-column for 2 days. Finally, TCMS diluted 1:4 was directly fed into the D-column for comparison.
TOC, $\mathrm{NO}_{3}^{-}-\mathrm{N}, \mathrm{NO}_{2}^{-}-\mathrm{N}$ and $\mathrm{SO}_{4}{ }^{2-}$ in the influent and effluent of each column were analyzed.

Batch tests

Test 1: Investigation of inhibitory effect of terramycin to denitrifiers

Denitrification rate under different terramycin concentrations was determined by using acetate $\left(500 \mathrm{mg}^{l^{-1}}\right)$ as the electron donor. The test was carried out in $500 \mathrm{ml}$ beakers on a jar tester. The mixing rate was $18 \mathrm{rpm}$, and the dissolved oxygen (DO) of the solutions was no more than $0.5 \mathrm{mg} \mathrm{l}^{-1}$. Samples were taken at an interval of $2 \mathrm{~h}$, and $\mathrm{NO}_{3}{ }^{-}-\mathrm{N}$ and $\mathrm{NO}_{2}-\mathrm{N}$ of the samples were determined.

\section{Test 2: Denitrification potential of TCMS diluted 1:99}

The denitrification potential of wastewater, which was defined as the amount of nitrate that could be reduced with the biodegradable COD in the influent, was determined. TCMS was diluted for 100 times to eliminate the possible inhibitory effects of compounds in wastewater to denitrification. The experimental procedure was the same as test 1.

Test 3: Aoailability of oxalate as electron donor for denitrification

The nitrate reduction rate based on oxalate $\left(1500 \mathrm{mg} \mathrm{l}^{-1}\right)$ was compared with that on acetate $\left(500 \mathrm{mg} \mathrm{l}^{-1}\right)$. A higher concentration of oxalate was used because the COD value of unit weight oxalate was very low. The experimental procedure also followed that in test 1 .

Test 4: Effect of aneerobic hydrolysis on reaction rates

The influent and effluent of the A-column (TCMS 
diluted 1:4, HRT 4 h) were sampled respectively to verify the effect of anaerobic hydrolysis on reaction rates of organics decomposition, denitrification and nitrification. The test of denitrification followed the procedure described in test 1 . For the oxidation/nitrification test, $400 \mathrm{ml}$ samples mixed with seed sludge of $2000 \mathrm{mgl}^{-1}$ were put into $500 \mathrm{ml}$ cylinders at room temperature. Aeration and mixing were provided by an air pump. Samples were taken at an interval of $6 \mathrm{~h}$, and TOC, $\mathrm{NO}_{3}-\mathrm{N}, \mathrm{NO}_{2}^{-}-\mathrm{N}$, and $\mathrm{NH}_{3}-\mathrm{N}$ of the samples were determined.

In order to ensure the reproducibility of the results, each test was conducted twice under equal experimental conditions.

Analyses

All samples were filtered with a $0.45 \mu \mathrm{m}$ filter before determination. The analytical methods were as follows: (1) $\mathrm{COD}_{\mathrm{Cr}}$ was on a rapid $C O D$ analyzing meter (CTL-12, Huatong, Chengde, Hebei); (2) $\mathrm{pH}$ and DO were measured with handy meters (pH, HM-14P; dissolved oxygen (DO), DO-11P, TOA Electronics Ltd., Japan) immediately after sampling; (3) $\mathrm{TN}, \mathrm{NH}_{4}{ }^{+}-\mathrm{N}$ and mixed liquid suspended solids (MLSS) were determined according to standard methods [13] (4) $\mathrm{NO}_{3}^{-}-\mathrm{N}, \mathrm{NO}_{2}^{-}-\mathrm{N}$ and VFA were determined using ion chromatography (IC100, YEW, Japan); (5)Terramycin was measured on ion chromatography (Dx 4000i with a PCX-100 analytical column, Dionex, USA)[14].

\section{RESULTS AND DISCUSSION}

\section{Characteristics of Raw Wastewater}

Before beginning the continuous flow experiments, two batch tests were conducted to investigate the possibility of direct denitrification with TCMS.
Inhibitory effect of terramycin on denitrification

In a predenitrification process, the denitrification step comes ahead of nitrification, and the denitrifiers will be the first microbial consortium to be affected if wastewater contains inhibiting compounds. So, the inhibitory effect of terramycin on denitrification was investigated, and the result is shown in Figure 2. It was found that the inhibitory effect of terramycin on denitrifier activity was significant. $100 \mathrm{mgl}^{-1}$ of terramycin produced a reduction of specific denitrification rate by ca. $50 \%$. The denitrifiers almost lost their denitrification activity at a terramycin concentration of 500 mgl-1. $^{-1}$.

Denitrification potential of TCMS diluted 1:99

The denitrification potential of wastewater was defined as the amount of nitrate that can be reduced with the biodegradable COD in the influent. Since reduction of $1 \mathbf{g}$ $\mathrm{NO}_{2}-\mathrm{N}$ to $\mathrm{N}_{2}$ needs the same amount of electrons as the reduction of $0.6 \mathrm{~g} \mathrm{NO}-\mathrm{N}$ to $\mathrm{N}_{2}$, the amount of electrons needed to reduce the residual $\mathrm{NO}_{3}-\mathrm{N} / \mathrm{NO}_{2}-\mathrm{N}$ was expressed as $\mathrm{NO}_{3}^{-}-\mathrm{N}+0.6 \times \mathrm{NO}_{2}^{-}-\mathrm{N}$ [15].

Figure 3 shows the result of denitrification using diluted TCMS (1:99) for electron supply. The concentration of nitrate was $40 \mathrm{mgl}^{-1}$ at the beginning of the test, and decreased as denitrification proceeded. The nitrate reduction rate became extremely slow after denitrification continued for 12 hours, and it was judged that the availability of denitrification electron donors in the wastewater was almost completely exhausted. The residual concentration of nitrate was $25.4 \mathrm{mg}$ $\mathrm{I}^{-1}$. So, TCMS diluted 1:99 could provide the amount of electrons for the reduction of $\mathrm{NO}_{3}-\mathrm{N}$ of 14.6 to nitrogen gas. However, the amount of nitrate in TCMS diluted 1:99 was $21.0 \mathrm{mg} \mathrm{l}^{-1}$. This is to say, the original electron donors in wastewater only permitted a maximum nitrogen removal of $70 \%$. It is clear that only a small portion of COD in TCMS

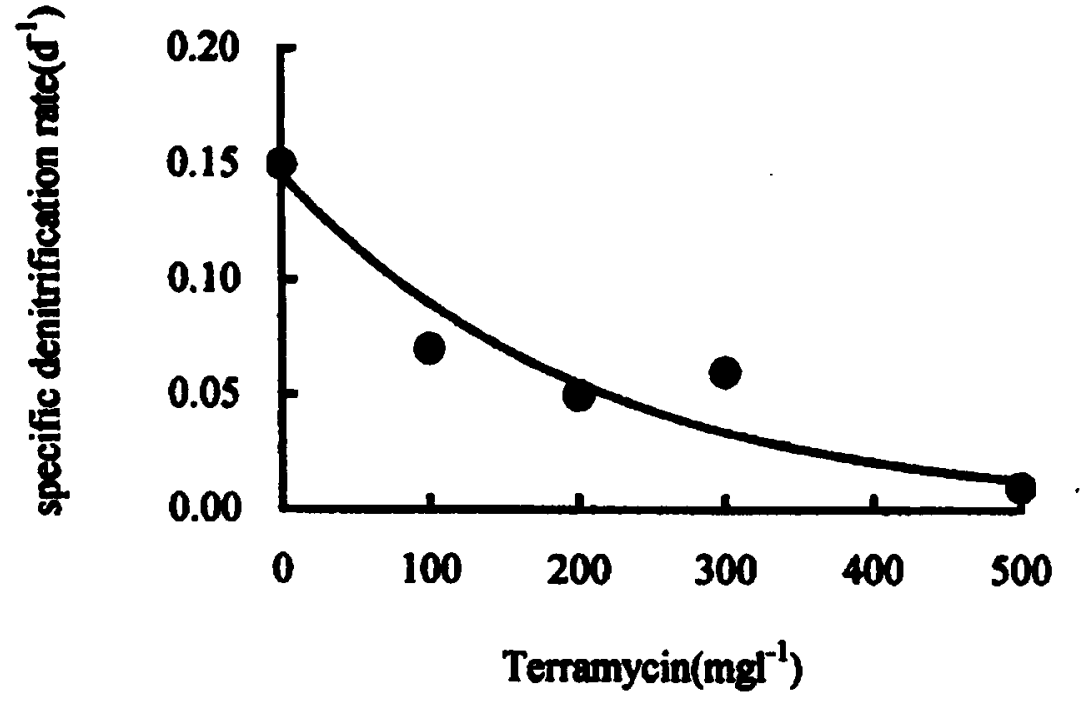

Figure 2. Inhibition of terramycin on activity of denitrifiers (Batch test: MLSS concentration, $2000 \mathrm{mgl}^{-1} ; \mathrm{pH}, 7.6-8.0$ ). 


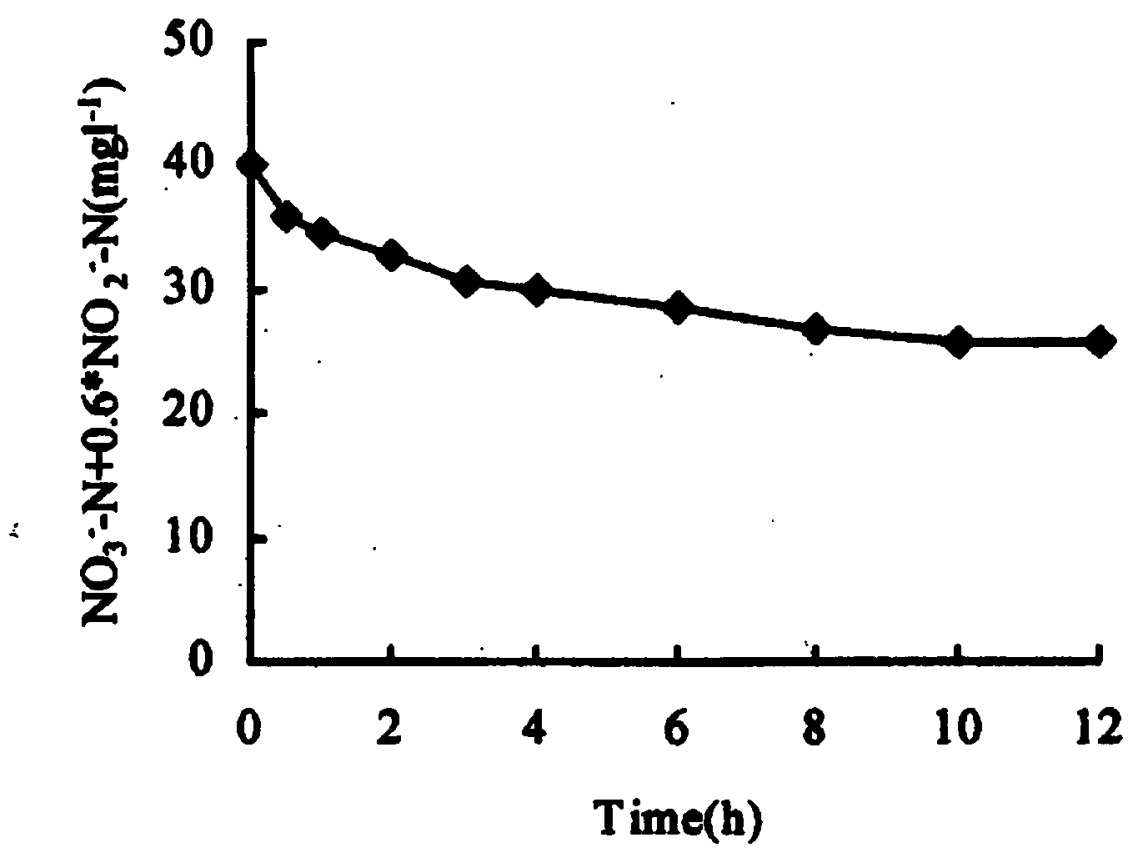

Figure 3. Denitrification of TCMS diluted 1:99 (Batch test: MLSS concentration, 2000 $\mathrm{mgl}^{-1} ; \mathrm{pH}, 7.6-8.0$ ).

can be directly utilized by denitrifiers. It was necessary to transfer a part of $C O D$ into effective electron donors for efficient denitrification.

Denitrification in the D-Column before and after Startup of the A-Column

Figure 4 shows denitrification performance of the Dcolumn. Its ORP was from -50 to $-100 \mathrm{mV}$. An average nitrate removal rate of ca. $80 \%$ was obtained in the first 19 days, and the denitrification performance began to deteriorate after the dilution ratio of TCMS was decreased from 1:49 to 1:35, which indicated a stronger inhibition to denitrifiers with the decrease of dilution ratio. So, the A-column was started up at day $\mathbf{5 0}$ and merged into the continuous flow treatment system for the purposes of reducing the inhibitory effects of TCMS. It was found, however, that the denitrification performance was not improved as expected. On the contrary, the nitrate removal rate decreased to a much lower level several days

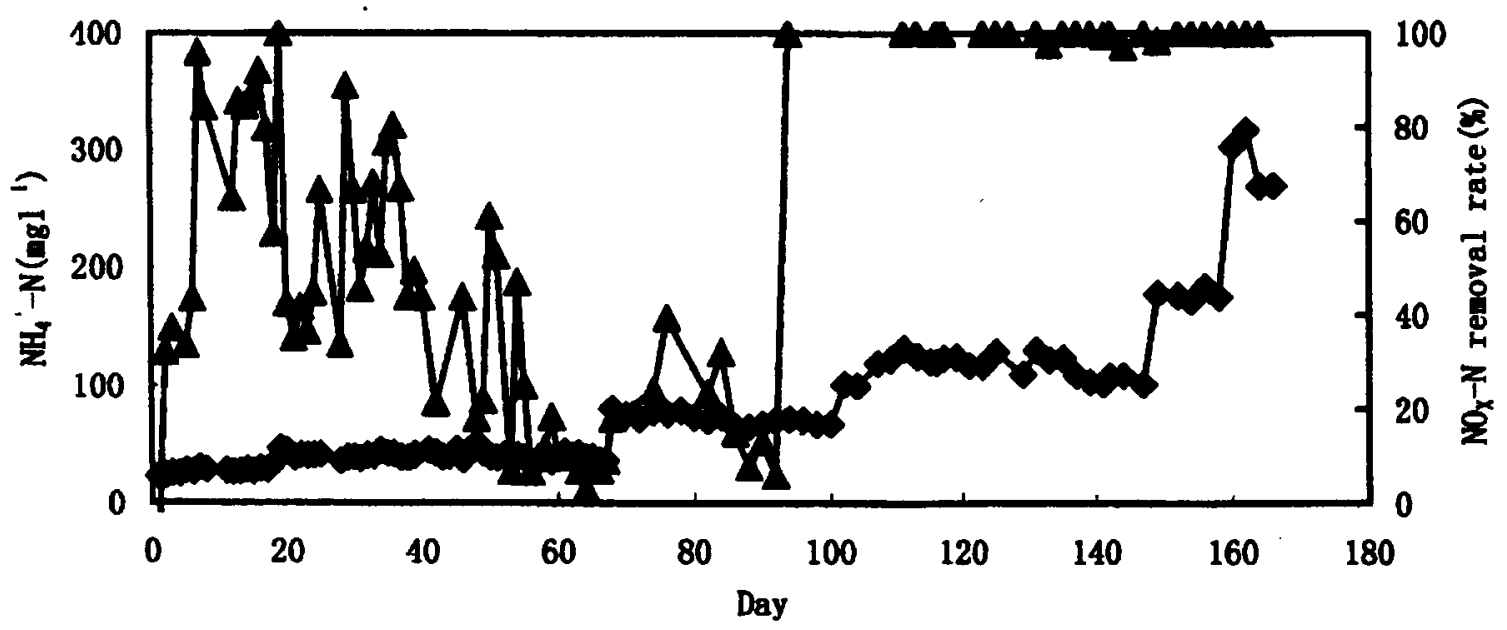

Figure 4. Variation in denitrification efficiency in D-column ( $\Delta$ Removal efficiency of $N_{x}-\mathbf{N}$ in $D-c o l u m n ;-N H_{4}{ }^{+}-N_{\text {in }}$ influent of continuous flow treatment system). 
later. Complete reduction of nitrate was suddenly achieved after the system was operated for 94 days (44 days after the startup of the A-column). From then on, nitrate residual in the D-column was seldom observed, and the nitrogen removal remained near $100 \%$ even when the dilution ratio was reduced to $1: 4$, which demonstrated the satisfactory stability of the whole system.

Variations nitrate removal in the first $\mathbf{5 0}$ days demonstrated that some components in TCMS might have inhibitory effects on denitrifiers. The inhibitory effects seemed to become stronger when the effluent of the A-column began to be fed to the D-column. Sankvist et al. [16] have studied the effects of antibiotics on biogas production from piggery waste, and found that the antibiotic itself may not inhibit bacterial activity but some metabolites produced in the gastrointestinal tract of the swine may do so. That is to say, some metabolites of antibiotics may have stronger inhibition effects than antibiotics themselves. It is possible that some metabolites of terramycin formed in the initial stage of anaerobic hydrolysis might have stronger inhibitory effects than terramycin itself. The fact that denitrification performance of the system was improved significantly after the A-column was operated for 44 days demonstrated that bacteria in the system began to be adapted to the toxins, or the toxins were further decomposed into other compounds with less toxicity.

Variations of Several Parameters in A-Column during Continuous Operation

The continuous flow treatment equipment consisted of anaerobic hydrolysis column, denitrification column and nitrification column was set up in this experiment. Its influent dilution ratio was decreased from 1:49 to $1: 4$ in the period of operation. The concentrations of all kinds of pollutants in the influent, as well as inhibitions, are increased along with the decreasing of influent dilution ratio. The ORP of the Acolumn was measured daily when influent dilution ratio decreased to $1: 4$. It was from -300 to $-350 \mathrm{mV}$. There were many reactions in the course of anaerobic hydrolysis. They were discussed according to the results of batch tests and column experiment.

$\mathrm{NH}_{4}^{+}-\mathrm{N}$

During the experiment, wastewater dilution ratio was reduced from 1:49 to $1: 4$ as indicated by the stepwise increase of influent $\mathrm{NH}_{4}^{+}-\mathrm{N}$ as shown in Figure 5. The concentration of $\mathrm{NH}_{4}{ }^{-}-\mathrm{N}$ in effluent of the A-column is also shown in Figure 5. Since some nitrogen-bearing organic compounds were included in wastewater, ammonification (formation of ammonium) occurred, increasing $\mathrm{NH}_{4}{ }^{+}-\mathrm{N}$ concentration in the A-column during anaerobic hydrolysis.

It can be seen from Figure 5 that $\mathrm{NH}_{4}{ }^{+}-\mathrm{N}$ concentration increased by $10 \%$ or so after anaerobic hydrolysis, and the production rate of $\mathrm{NH}_{4}{ }^{+}-\mathrm{N}$ in the A-column was maintained at almost the same level during the whole operation period, indicating that the ability of anaerobic sludge to degrade organic nitrogen compounds was not effected in spite of the increase in concentration of potential inhibitory compounds with the decrease in dilution ratios of TCMS. So, the anaerobic hydrolysis column has strong adaptability to terramycin crystallizing mother solution.

\section{Terramycin degradation}

Since terramycin could depress microbial activities, its variation in the A-column was monitored. The concentrations of terramycin in the influent and effluent were 74.5 and 36.4 $\mathrm{mg} \mathrm{l}^{-1}$, respectively under a dilution ratio of 1:4 and HRT of $1.5 \mathrm{~h}$. That is to say, $51.1 \%$ of terramycin was removed in the A-column.

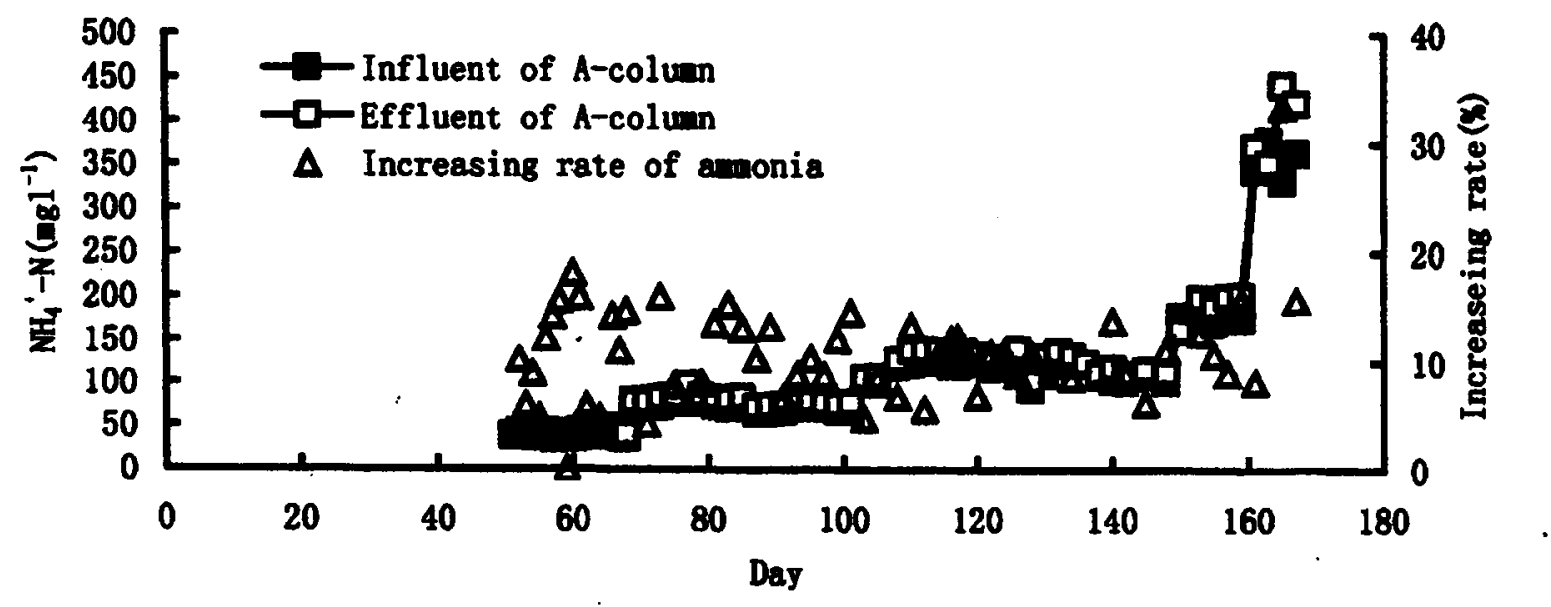

Figure 5. Production of $\mathrm{NH}_{4}^{+}-\mathrm{N}$ in A-column. 
The suitable conditions of terramycin decomposition, however, were not able to be clarified in this study. Since terramycin itself is a COD and nitrogen source, and terramycin as well as its metabolites, might be toxic to microorganisms as discussed above, further studies on its decomposition are required.

\section{Reduction of COD, sulfate and oxalate}

The COD removal rate of the $A$-column was at an average value of $16.0 \%$ during the whole operation period of 117 days, and did not change much under different influent loads. The TOC removal rate, however, was as high as $27.4 \%$. The discrepancy between the removal rates of COD and TOC was mainly due to sulfate reduction in the A-column [17].

Figure 6 shows variations in sulfate concentration in the continuous flow treatment system under the dilution ratio of 1:4. Sulfate experienced a significant reduction in the Acolumn, but then increased in the D-column and the $\mathrm{N}$ column. It was calculated that $\mathbf{4 8 . 5 \%}$ sulfate originated from denitrification. Sulfate in the influent was reduced to sulfide, which could be used as a kind of electron donor for denitrification [18]. It is possible that sulfate was formed again in the D-column through utilization of sulfide by denitrifiers.

Variations in oxalic acid in the A-column were also determined. It was found that oxalic acid in TCMS was almost completely removed during anaerobic hydrolysis. A batch test was designed to study the availability of oxalate as an electron donor for denitrification, and the experimental result is shown in Figure 7. Compared with the plot of denitrification based on acetate, the nitrate reduction rate

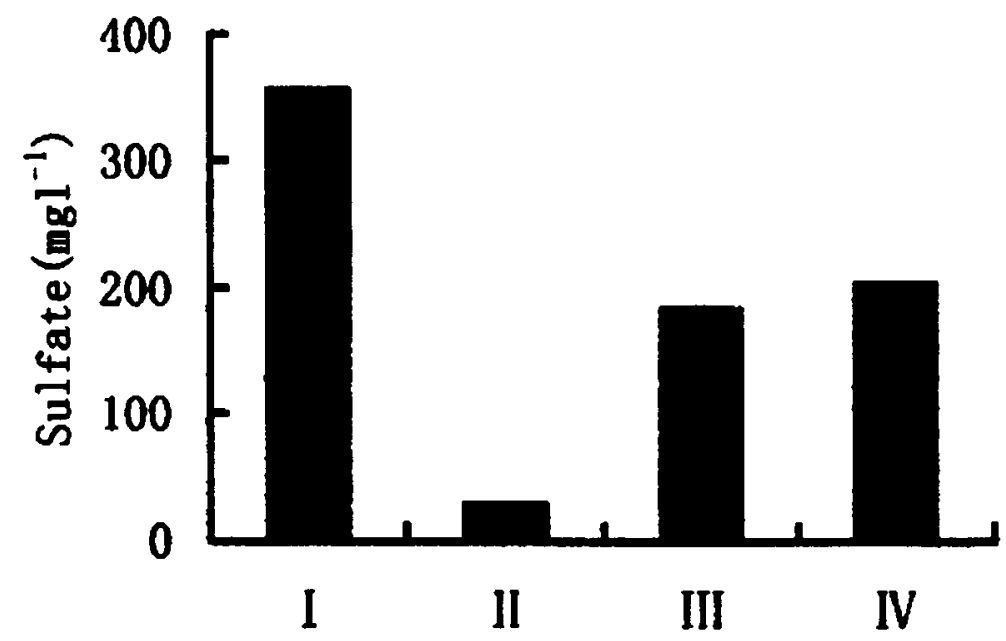

Figure 6. Concentrations of sulfate in influent and each column of continuous flow column system fed TCMS diluted 1:4 (I:Influent; II:A-column; III:D-column; IV:N-column).

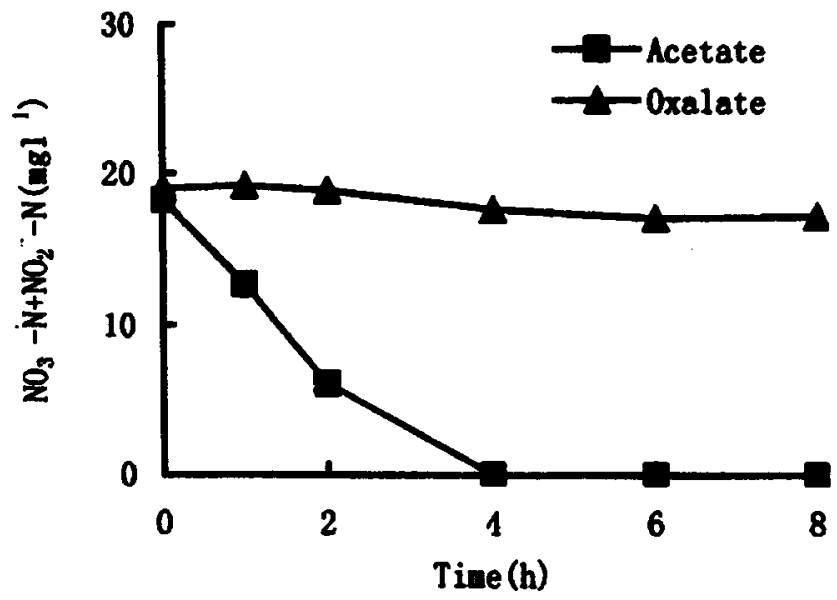

Figure 7. Denitrifications with oxalate or acetate as electron donor (Batch test: MLSS concentration, 2000mgl-1 $; \mathrm{pH}^{-7.6-8.0)}$ ). 
based on oxalate was extremely low, indicating that oxalate could not be used as an effective electron donor. It has been proven that oxalate could be easily degraded anaerobically to formate, which could be utilized by sulfate reducing bacteria $[19,20]$. So, the possible transfer of electrons from oxalate to sulfide, an effective electron donor, might benefit denitrification in the D-column.

\section{Formation of acetate}

Significant formation of VFA (mainly acetate), which has often been used as a favorable electron donor for denitrification, was observed in the effluent of the A-column during continuous operation. Acetate concentration increased from almost nil to $650 \mathrm{mgl}^{-1}$ in the A-column under the dilution ratio of $1: 4$, which possibly contributed to the improvement in denitrification performance.

Effect of HRT of A-Column on Availability of Electron Donors for Denitrification.

Solution fed to the D-column was dosed with excessive nitrate. So, the COD components available to denitrification from the effluent of the A-column could be consumed completely in the D-column, and the amount of $\mathrm{NO}_{3}^{-}-\mathrm{N}$ reduced in the D-column could be used for evaluating the availability of electron donors. The $\mathrm{NO}_{3}-\mathrm{N}$ reduced in the $\mathrm{D}$ column as well as variations of sulfate and TOC in the effluents of the A-column against HRT of the A-column are shown in Figure 8. It was found that the sample fed to the D. column without anaerobic hydrolysis only permitted a reduction of $\mathrm{NO}_{3}^{-}-\mathrm{N}$ of $18.5 \mathrm{mgl}^{-1}$. The reduction of $\mathrm{NO}_{3}^{-}-\mathrm{N}$ increased to $110.4 \mathrm{mgl}^{-1}$ if the influent of the D-column was anaerobically treated for only $1 \mathrm{~h}$, and remained almost constant at a value of $121.3 \mathrm{mgl}^{-1}$, about 6 times that without pretreatment, in an HRT range from $2.5 \mathrm{~h}$ to $6.0 \mathrm{~h}$. So, an HRT of 1 or $\mathbf{2 h}$ was sufficient for increasing the amount of electron donors.

Variations in sulfate and TOC in the effluents of the Acolumn demonstrate that the reduction of sulfate and decomposition of organics were accomplished at the HRT of $2.5 \mathrm{~h}$. TOC removal stopped for some reason after sulfate reduction ended. However, the stop of TOC decomposition was favourable in this case since a lot of electron donors were needed for sufficient denitrification.

Effects of Anaerobic Hydrolysis on Denitrification and Nitrification/Oxidation Rates

The effluent of A-column at an HRT of $4.0 \mathrm{~h}$ was sampled to determine denitrification and nitrification/oxidation rates in batch tests. Its influent was used as control.

\section{Denitrification}

Nitrate reduction rate based on effluent from the Acolumn is compared with that on influent in Figure 9. The HRT of the A-column was $4 \mathrm{~h}$, and the dilution ratio was 1:4. It can be calculated from Figure 9 that the specific denitrification rates were $0.045 \mathrm{~d}^{-1}$ and $0.033 \mathrm{~d}^{-1}$ respectively. Thus, not only the electron donor amount but also the nitrate reduction rate of TCMS was increased through anaerobic hydrolysis in the A-column. The rise in denitrification rate was possibly due to two factors, i.e., the formation of smaller and simpler molecules and the reduction of inhibitory effects through anaerobic hydrolysis.

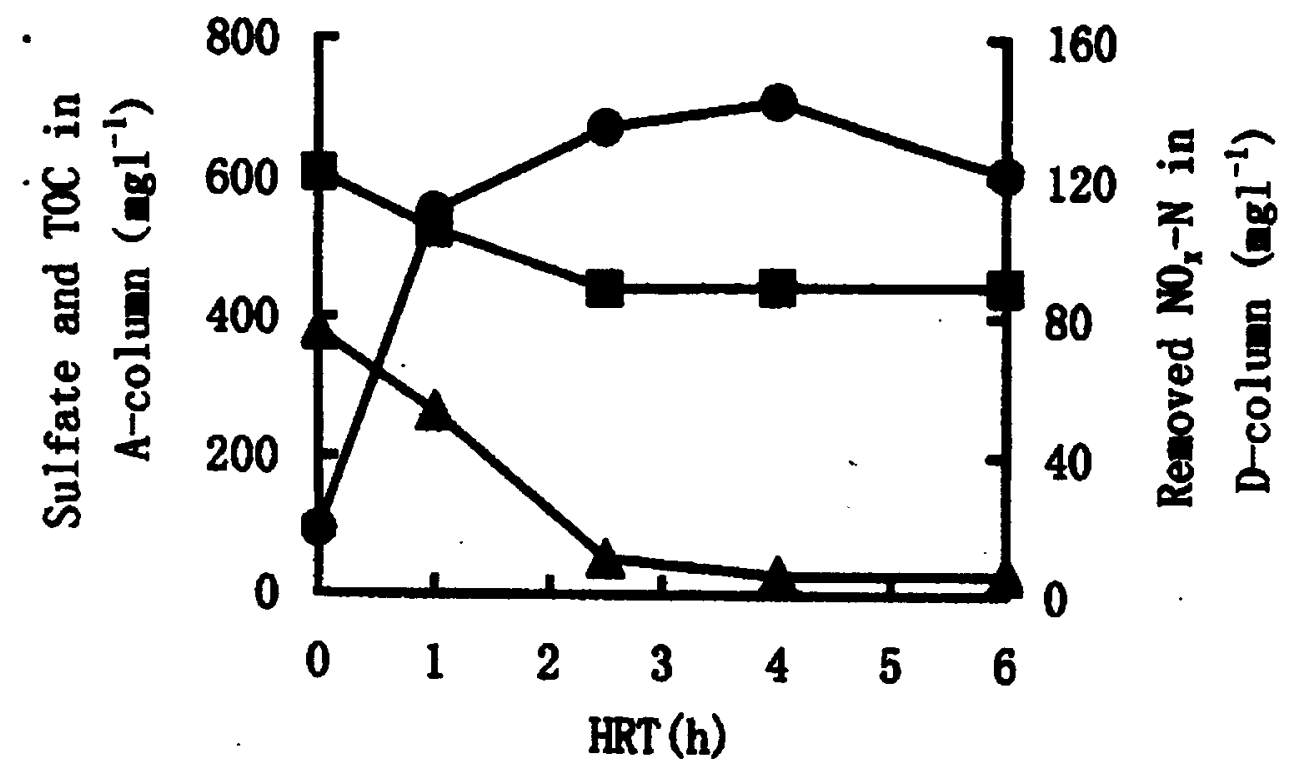

Figure 8. Effects of A-column HRT on availability of denitrification electron donors ( $\left.\triangle \mathrm{SO}_{4}{ }^{2-} ; \mathrm{TOC} ; \mathrm{ORemoved} \mathrm{NO}_{\times}-\mathrm{N}\right)$. 


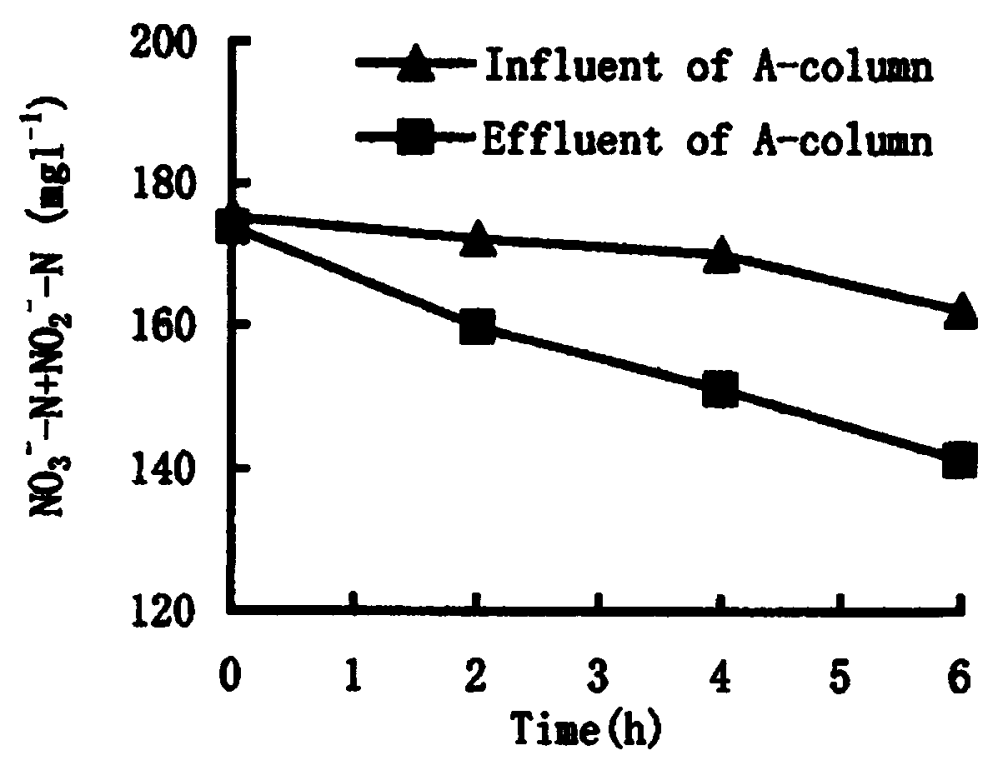

Figure 9. Denitrifications with influent and effluent of A-column fed with TCMS diluted 1:4 (batch test: MLSS concentration, $\left.2000 \mathrm{mg} \mathrm{l}^{-1} ; \mathrm{pH}, 7.6-8.0\right)$.

\section{Oxidation/Nitrification}

The same samples were also used for evaluating the improving effects of anaerobic hydrolysis on the speed of TOC removal efficiency and nitrification rate (Figure 10). It is obvious that organics decomposition of the sample without anaerobic hydrolysis can be divided into two steps: the fast step (the first 12 hours) for the readily biodegradable matter and the slow step (the latter 18 hours) for the complicated molecules. For treating A-column effluent, the amount of organics with a low degradation rate was reduced, and the time for the slow step was shortened to about 6 hours. This showed that some complicated organios may be degraded

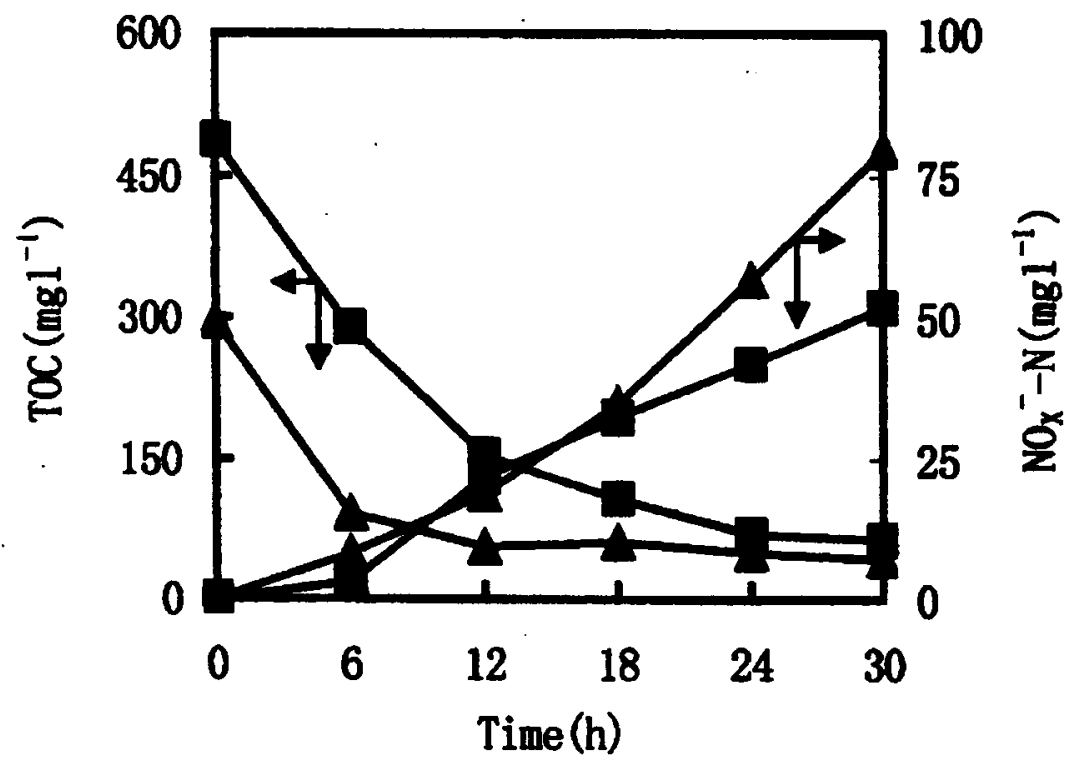

Figure 10. Organios decomposition and nitrification in influent and effluent of A-column fed with TCMS diluted 1:4 (Batch test: MLSS concentration, 4000 $\mathrm{mgl}^{-1} ; \mathrm{pH}, 7.6-8.0$; $\mathrm{TCMS}$ diluted 1:4; $\triangle$ Effluent of A-column). 
into simple molecules in the course of anaerobic hydrolysis. On the other hand, it was found that the specific nitrification rates of the samples with and without anaerobic hydrolysis were $0.021 \mathrm{~d}^{-1}$ and $0.010 \mathrm{~d}^{-1}$ respectively after most of the biodegradable organics were removed. So, anaerobic hydrolysis benefits both TOC removal and nitrification.

\section{CONCLUSION}

Based on the findings of this study, the following conclusions can broadly be drawn:

1. Although the COD of TCMS was very high, a great part of COD was not directly available to denitrifiers as electron donors. Anaerobic hydrolysis was very effective in promoting denitrification by producing favourable electron donors such as acetate and sulfide. Electrons available for denitrification were increased by 6 times after diluted TCMS was anaerobically treated under an HRT of $2.5 \mathrm{~h}$ or longer.

2. The reaction rates of nitrification and denitrification were significantly increased after anaerobic hydrolysis. The increase in reaction rates was attributed to possible reduction of inhibitory compounds like terramycin and decomposition of complicated molecules to small ones.

3. The anaerobic hydrolysis/denitrification/nitrification process was effective for simultaneous removal of organic compounds and nitrogen from terramycin crystallization mother solution.

\section{REFERENCES}

1. Chen, Y., Liu, F., Wang, J.C. and Dong, J.P., Study on pharmaceutical wastewater treatment by UASB. Environ. Sci. 15, 50-52 (1994) (in Chinese).

2. Guo, Y.J., The study on the treatment of mixed wastewater of terramycin and medemycin. Environ. Pro. Chem. Ind., 10, 199202, 214 (1990) (in Chinese).

3. Lu, Z.Y., Wang, Y.J. and Ren, L.R., Exploration on cultivating granular sludge in UASB reactor treating streptomycin wastewater. China Biogas 15, 11-15 (1997) (in Chinese).

4. Yang, J., Lu, Z.Y., Hu, J.C. and Gu, X.S., Biological treatment technology of antibiotic industry wastewater. Environ. Sci., China, 18, 83-85 (1997) (in Chinese).

5. Glass, C. and Silverstein, J., Denitrification kinetics of high nitrate concentration water: pH effect on inhibition and nitrite accumulation. Water Res. 32, 831-839 (1998).

6. Spalding R.F. and Exner M.E., Occurrence of nitrate in groundwater-A review. J. Enoiron. Qual 22, 392-402(1993).

7. Ines M., Soares, M. and Abeliovich, A., Wheat straw as substrate for water denitrification. Water Res. 32, 3790-3794 (1998).

8. Hallin S., Rothman M. and Pell M., Adaptation of denitrifying dacteria to acetate and methanol in activated sludge systems. Water Res., 30, 1445-1450 (1996).

9. De Renzo D. J., Nitrogen Control and Phosphorus Remooal in Sewage Treatment. Noyes Data Corporation, New Jersey, USA pp.55-58 (1978)

10. Cross W. H., Chian E. S. K., Dohland F. G., Harper S. and Cheng S. S., Anaerobic biological treatment of coal gasification effluent. Biotechnol. Bioeng. Symp. 12, 349-363 (1982).

11. Fedorak P. M. and Hrudey S. E., Anaerobic treatment of phenolic coal conversion wastewater in semi-continuous cultures. Water Res. 20, 113-122 (1986).

12. Suidan M. T., Strubler C. E., Kao S. W. and Pfeffer J. T., Treatment of coal gasification wastewater with anaerobic filter technology. J. Water Pollut. Control. Fed. 55, 1263-1270 (1983).

13. Chinese Environmental Protection Agency. Water and Wastewater Monitoring and Analyzing Methods, 3rd ed., Environmental Science Press of China. Beijing. (1998) (in Chinese).

14. Ding, X.J. and Mou, S.F., Ion chromatographic analysis of terracyclines using polymeric column and acidic eluent. J. Chromatogr. A, 897, 205-214 (2000).

15. Kujawa, K. and Klapwijk, B., A method to estimate denitrification potiential for predenitrification systems using NUR batch test, Water Res. 21, 2291-2300 (1999).

16. Sankvist, A., Hagelberg, M. and Mathisen, B.,. Effect of antibiotics and chemotherapeutics on biogas production from piggery waste. Bioenergy 84, 422-426 (1984).

17. Barber W.P. and Stuckey D.C., Effect of sulfate reduction on chemical oxygen demand removal in an anaerobic baffled reactor. Water Environ. Res. 72, 593-601(2000).

18. Zhang T.C. and Lampe D.G., Sulfur:limestone autotrophic denitrification processes for treatment of nitrate-contaminated water: Batch experiments. Water Res. 33, 599-608 (1999).

19. Allison M. J., Dawson K. A., Mayberry W. R. and Foss J. G., Oxalobacter formigenes gen. nov. sp. nov.: oxalate-degrading anaerobes that inhibit the gastrointestinal tract. Arch. Microbiol. 141, 1-7 (1985).

20. Dinsdale R.M., Hawkes F.R. and Hawkes D.L., Anaerobic digestion of short chain organic acids in an expanded granular sludge bed reactor. Water Res. 34, 2433-2438 (2000). 